\title{
Understanding the Belt and Road Initiative
}

\author{
Dinesh Bhattarai, PhD \\ Former Ambassador/Permanent Representative to the United Nations of Nepal \\ Email: dineshbhattarai1@gmail.com
}

\begin{abstract}
China's project of the century-Belt and Road Initiative - is a signature foreign policy project of President Xi Jinping. Launched in 2013, BRI contains two components- overland belt connecting China with Central Asia, Russia, South Asia and Europe, and Maritime Silk Road for enhancing connectivity, and maritime cooperation linking Chinese ports with Southeast Asia, South Asia, Africa, the Middle East and Europe. BRI wraps up these two initiatives in it and intends to cover the number of countries along the route that happens to be the biggest market in the world with enormous potentials for trade and investment cooperation. BRI has both economic and strategic messages behind a massive infrastructure plan covering a vast network of connectivity linking 60 countries.
\end{abstract}

BRI has sparked a variety of responses, some welcoming and supporting it, some expressing reservations, some willing to participate "for shaping the outcome from within", and some wanting it to firmly match the international standards of transparency, openness, and the fiscal soundness of the country. Nepal formally became a part of BRI by signing a Memorandum of Understanding on Framework Agreement in May 2017 for enhancing more connectivity and integration, though Nepal is not included in any of the six economic corridors unveiled by China. China recently suggesting Nepal to trim projects from 35 to 9 reflects the standard of the work done by the Nepali government and its lack of preparedness and seriousness. Infrastructure development is key to progress and prosperity. As China remains engaged in improving connectivity in the neighborhood, there is a great optimism about BRI in Nepal. Against this background, this article looks at the significance of BRI, examines past attempts made at connectivity, responses to BRI and Nepal's participation in it.

Key words: China, President Xi, maritime, Silk Road, connectivity, collaborative measures

\section{Introduction}

The Belt and Road Initiative (BRI) is China's signature foreign policy project of President Xi Jinping. The project has completed almost half a decade of constructional phase. Within this phase, it has gone through several conceptual adjustments. The project has come along with 'Xi Jinping Thought on Socialism with Chinese Characteristics for a New Era', and has been enshrined in the Chinese Communist Party's constitution. BRI reflects China's ascendancy to global power politically, economically and strategically. It also symbolizes China's resurgence as a world power through China's tacit influences in various sectors using visible economic cooperation as an approach to access resources of participating countries. BRI seeks to link China with Central Asia, South Asia, Russia, Europe, North Africa/Southwest Asia, and northern parts of Sub-Saharan African countries (Fig. 1). Passing through the ancient Silk Road and utilizing already built Chinese roads, railways, ports and pipelines, and trade routes, BRI will increase people-to-people contacts through various cooperation schemes that would help China to come at par with the USA (Kummer, 2017). Aiming to accomplish Beijing's geopolitical goals, it tries to break perceived US encirclement in the Indo-Pacific region and constrain the growth of India in South Asian region (Times of India, 2017). The Maritime Silk Road also connects Chinese ports with Southeast Asia, South Asia, Middle East and North African (MENA) countries, Sub-Saharan African countries (mainly Kenya), and Europe (Fig. 1 with Table). It is described as the project of the century with an estimated investment of \$4-8 trillion (Rana, 2017).

In the past four years, about 100 countries and international organizations have supported this initiative. In 2017, some resolutions of the UN General Assembly and Security Council refer to it. China's total trade with other "Belt and Road countries in 2014-2016 was over US \$3 trillion, and China's investment in these countries crossed US $\$ 50$ billion" (Rana, 2017). "Chinese companies have set up nearly 60 economic cooperation zones in 20 countries, generating over US \$1 billion of tax revenue and some 180,000 jobs in these countries" (Rana 2017:2). The Economist (2017) stated that the 'one belt, one road' (OBOR) will consist of 900 infrastructure projects, valued at about US \$1.3 trillion. Much of the funding is expected to come from Chinese banks, financial institutions, and special funds from China (Bilal 2017). Other funds may come from the Asian Infrastructure Investment Bank (AIIB) and the New 
Development Bank of the Brazil, Russia, India, China and South Africa (BRICS). Already, Beijing has over US \$100 billion fund for "Silk Road". Critiques argue that only about half the announced funds actually materialize, and the pledges amount will not be available because the BRI is unlikely to produce returns commensurate with the investments and many businessmen are withdrawing from investments. Since its goals have been changing over time, several countries are still in wait and see approach to determine their full participation in this initiative (The Times of India 2017). Many consider this mega project of China as a challenge to the United States (U. S.) more directly than any Chinese leaders have had with different strategies since Mao Zedong. This BRI project has become one of the major concerns of the U. S. as China has plans to modernize its army by 2035 and "achieve a world class military by 2050 that could fight and win wars" (Bijian, 2017).

\section{Figure 1: The Network of Proposed Belt Road Initiatives}

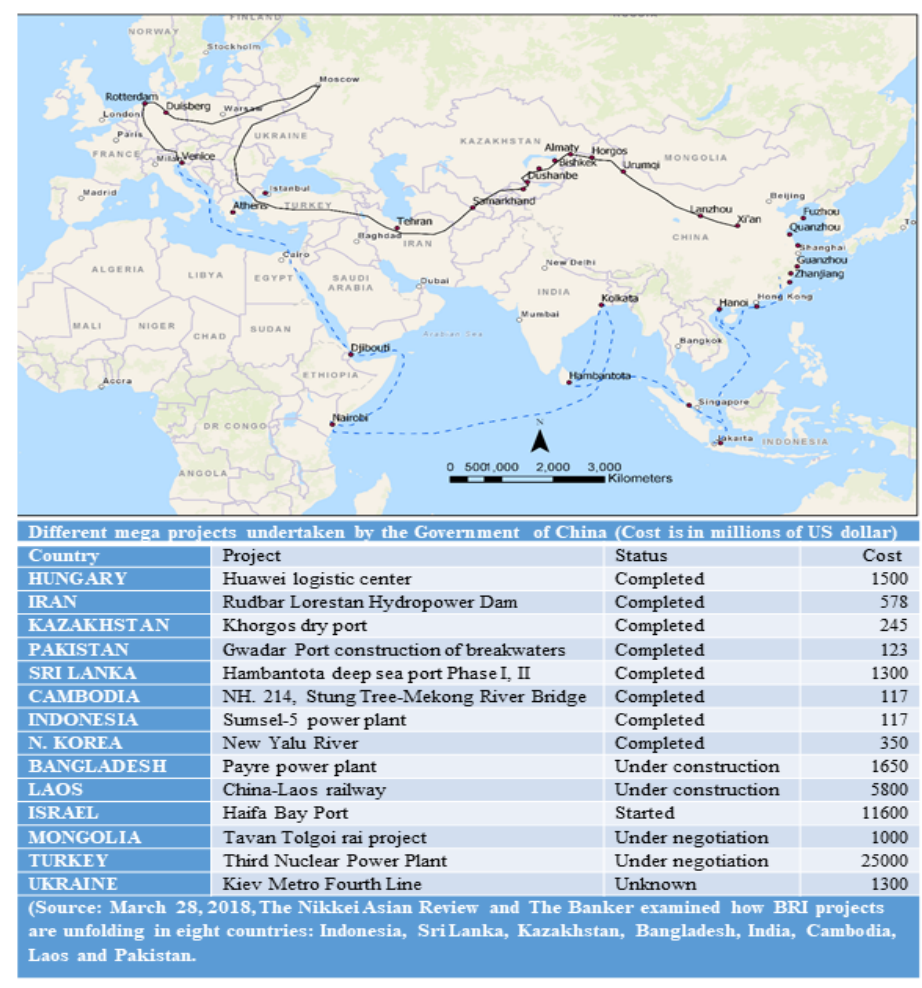

China is taking this BRI as her major "agenda for strategic expansion on the global agenda" (Kummer, 2017; Stratfor, 2018). China is aggressively expanding her influences through increasing economic, technical assistance, naval skills and power projection capabilities to make this BRI a success. This is causing a large headache for established, emerging middle and small powers alike. U.S. announcement of its intention to develop opportunities in the fields of digital economy, infrastructure, trade, investment, and energy across the Indo-Pacific region is seen as an approach to contain the rising influence of China and the expansion of BRI in the region. U.S. concerns for "free and open" environment where states "thrive in freedom and peace", and independent countries "play by the rules" are being challenged by Beijing. Contrary to U.S. position, Beijing terms democracy as a chaotic and instable system. These ideas are perceived to have come wrapped in a package of BRI, whose implementation has become the top diplomatic agenda of the Chinese foreign policy.

The BRI is intended to forge an integrated and extensive network of regional infrastructures with China at its hub (Yu, 2017). This network not only would benefit over three billion people representing the biggest market in the world with enormous potentials, but also would have great impacts in global politics, security and economy. This will break the old order and China in its extraordinary economic success while influencing leaders of impoverished countries that are touched by the BRI (Bijian, 2017). These developments are making China an influential factor in internal electoral politics, particularly in Pakistan, Malaysia, Sri Lanka (Yu, 2017), and the Maldives (2017).As of now, India is not in agreement with the BRI, but China has proposed to have maritime connection with Indian port of Kolkata (Fig. 1).

This article briefly first, looks at the background of the BRI in terms of connectivity and unfolding geopolitical transformation. Second, it seeks to answer how China's dreams, of building a "community of common destiny" through BRI, would affect the geopolitics of Asia in general and the Indo-Pacific region in particular. Third, it looks at the significance of the initiative in the context of evolving Chinese foreign and security policy. In this section, it reviews the past attempts made including by China for wider connectivity using Silk Road. Fourth, it reviews various responses from countries and agencies. Fifth, it presents Nepal's responses to BRI and partnership with this mega project. The final part is about conclusion followed by references.

\section{Evolution of BRI}

The concept of BRI first emerged from a speech by President Xi at the Nazarbayev University, Astana (Fig. 1), capital city of Kazakhstan, on 7 September 2013. In his address, President Xi proposed to jointly 
build an "economic belt along the Silk Road" linking his home province Shaanxi, as the starting point of the ancient Silk Road, to Astana (President Xi, 2013). This route was very much used by steady stream of envoys, caravans, travelers, scholars and artisans travelling between the East and the West. This Silk Road was also instrumental for the exchanges between the Eastern and Western civilizations and a media for the interactions and cooperation between various nations and cultures. This overland belt connected China with Central Asia, Russia, South Asia, and Europe. Creating an "economic belt along the Silk Road" is a great undertaking that will benefit almost three billion people of various cultures and traditions. This will create the biggest market in the world with enormous potential for trade, investment and cooperation between the relevant countries (President Xi, 2013).

On October 2, 2013, President Xi in his speech at Indonesia's Parliament talked about the Maritime Silk Road to increase connectivity and maritime cooperation with the Association of Southeast Asian Nations (ASEAN). The maritime road connected Chinese ports situated in Southeast Asia, South Asia, Africa, the Middle East and Europe (Fig. 1). President Xi wants China to become 'global leader in terms of comprehensive national strength and international influence by midcentury.' These steps of President Xi are unveiling the 'dream of the great rejuvenation of the Chinese nation.' The two speeches given in Nazarbayev in Kazakhstan and Indonesia were combined to form a unified concept known as Belt and Road Initiative (BRI). This grand initiative, comprising various routes by sea and land, is intended to connect China with Southeast and South Asia, Central Asia, Pacific Oceania, Africa and Europe. It is centered on both soft and hard infrastructure connectivity, aiming to forge an integrated and extensive network of regional infrastructure with China at its hub (Yu, 2013).

On 14 May 2014, China hosted the opening ceremony on the Belt and Road Forum for International Cooperation with a theme of "Work Together to Build the Silk Road Economic Belt and the $21{ }^{\text {st }}$ Century Maritime Silk Road." This ceremony was attended by 60 nations including 28 heads of State. In this conference, President Xi called the BRI as a project of the century. He further said that BRI would be the only showcase that would span thousands of miles. Within such a wide area, the BRI would help maintaining peace and cooperation with inclusiveness, mutual learning and mutual benefit. The Silk Road spirit has become a heritage of human civilization (President Xi, 2017). Bijian (2014) described the May 14 conference on BRI as the next phase of globalization that promises a new foundation for shared growth of global engine. Bijian (2017) further said it is about building upon converging interests and fostering communities of interests with "cooperative development."

President Xi (2017) argued that the silk routes not only helped in trade (Chinese exporting silk, porcelain, lacquer work and ironware to the West, Chinese also importing pepper, flax, spices, grape and pomegranate from Southwest and Southeast Asia into China), but also helped to exchange knowledge. Additionally, these routes also facilitated the spread and exchange of religions; for example, Buddhism spread into Southeast Asia (Myanmar, Thailand, Cambodia, Laos, and Japan) and Islam penetrated into the western part of China (Xinjian, Ningxia, Gansu, and Quighai), southern part of Thailand, western part of Myanmar, Malaysia, all over Indonesia. Confucianism, which was born in China, appreciated much by the European thinkers such as Leibniz and Voltaire spread worldwide through this route. Calendars and medicines produced in the Middle East and Persia penetrated into China through these routes. The Silk Road also facilitated in the exchange of technology; for example, the exchange of silkworm breeding technology in different countries (President Xi, 2017)."

Within four years of the beginning of this project, over 100 countries and international organizations have supported and got involved in this initiative, and even the UN in its one of the important resolutions at the General Assembly and Security Council of 2017 mentioned about the BRI (Xi, 2017). The BRI has compressed spatial distances connecting many distantly located places. It has been instrumental in strengthening the friendship, sharing development, maintaining peace and harmony and making the future better. China has pledged substantial investment and made diplomatic commitments to countries in the belt. In his three and half hours speech in the $19^{\text {th }}$ National Congress of the Communist Party of China (CPC) in October 2017, President Xi termed his first term as 'truly remarkable,' in which, China 'stood up, grown rich and become strong.' He declared, "It is time for us to take centre stage in the world and to make a greater contribution to humankind." He recommended other countries to draw on 'Chinese wisdom and follow' a Chinese approach to solving the problems facing the humankind. This brings China's governance model at the front and center of its foreign policy, erasing the dividing line between domestic and foreign policy. These remarks of President Xi suggest that Beijing is seeking to export its political values across the globe. There are widespread perceptions that China wants to perpetuate its 
model of economic development with the robust engagement of the countries in Asia, Europe and Middle East through this BRI.

\section{Significance of BRI}

The BRI has made a departure from the long-held policy of Deng era"biding time and building capabilities" and "keeping a low profile in international affairs" (Bijian, 2017).Over the years, "the source of [Chinese Communist] party's legitimacy has undergone changes from ideology to performance to nationalism."'Foreign policy has now become assertive and proactive in a multipolar world. China is aiming to provide leadership to the world through its foreign policy decision making and is determined to reshape the world order (Yu, 2017).Chinese leadership has leveraged its financing, strong manufacturing base and infrastructure development capacity, as well as its political and diplomatic resources at its disposal to present China as a global power. The journey to "great national rejuvenation" will be towards the achievement of the two "centenary goals."When Chinese communist Party celebrates its hundredth anniversary in 2021, Chinese leaders aim at building an "overall moderately well-off society" with per capita income of $\$ 7000,60 \%$ urbanization and a life expectancy at birth of 76 years, (Xi 2014, Rolland,2015). In 2049- the hundredth year of the founding of the People's Republic of China, China aims to become a "modern socialist country that is prosperous, strong, democratic, culturally advanced, and harmonious" (Xi 2014, Clarke, 2017). This reflects the wish of Chinese leadership to make China 'global leader in terms of comprehensive national strength and international influence by midcentury.' This would have far-reaching political, social, economic and strategic implications both at home and abroad.

BRI is the biggest initiative by any country since the launching of Marshall Plan to rebuild post World War II Europe. It is taken as China's Marshall Plan with promises to invest over $\$ 1$ trillion in infrastructure development. The initiative is presented as a win-win proposition. Its reach is wide, and implications go far-and-wide. The initiative is not merely the sum of its infrastructure projects. It is rather "seen as a strategy with a clear set of ends, ways and means to be evaluated on its ability to support China's geopolitical objectives (Qayyum, 2015). The essence of BRI "is to divert China's strategic attention and resources to engage countries in China's western flank including Central Asia, West Asia, South Asia and beyond, and avoid direct and high intensity confrontation with other major players in the Asia-Pacific" (Li, 2016). China's aims also include ideals to link its inland cities to global markets with a diversified network of transit routes and energy pipeline, many of which would take inland routes and serve as alternatives to existing sea-lanes $(\mathrm{Li}, 2016)$.This is seen as a step forward to China becoming "one day a rule shaper in the global arena and regain a position of pre-eminence in the world" (Yu, 2017).

BRI has great significance in the modernization because China considers physical infrastructures as the first step towards integration and creation of economic corridors in the $21^{\text {st }}$ century. China's international strategy includes among others, "retaining control of the economy", "building hard power, leading regional integration with Chinese characteristics", and "deploying sharp power along with traditional use of soft power which is more coercive and intrusive" (The Economist, 2014).

\section{Shifting Power from the Euro-America to Eurasia}

With the BRI, China aspires to shift the global center of gravity from Euro-America to Eurasia and it is considered as a counter-weight to US influence. BRI envisions creating world order in deference to Chinese interests and peace and stability for prosperity. To support this move, China has created financial institutions to fund BRI, and earmarked hundreds of billions of dollars on the projects across Eurasia. Beijing has enlisted various existing regional cooperation mechanisms like Shanghai Cooperation Organization (SCO), Association of South East Asian Nations (ASEAN), Asia Pacific Economic Cooperation (APEC), and Greater Mekong Subregion in this plan. China will spend billions of dollars to build ports, pipelines, roads and telecommunication facilities across the countries that have joined BRI. It is an ambitious endeavor, encompassing as many as 900 projects more than 80 of which are contracted to Chinese firms (Economy, 2015). Along with BRI, China has taken multipurpose projects. For example, in Pakistan, the plan includes not only railroads, highways and dams, but also a proposal to develop a system of video and Internet surveillance similar to that in Beijing and a partnership with a Pakistani television channel to disseminate Chinese media content (The Economy, 2018). China runs ports and terminals in 34 countries including in Greece, Pakistan, Djibouti, and Sri Lanka, which provide China an opportunity to advance its military objectives (Fig. 1). 
China came out with six economic corridors as part of BRI where it would enhance existing transportation networks, construct new roadways and build intermodal transport hubs and energy pipelines along with power plants and communication technology such as fiber-optic cables. The six economic corridors (Fig. 1) are as follows (Qayyum, 2015):

- The China-Mongolia-Russia corridor, anchored by the Trans-Siberian railway;

- The New Eurasian Land Bridge, anchored by a set of railways running from central China (Wuhan, Chongqing and Chengdu) to Europe via Kazakhstan, Russia and Belarus

- The China-Central Asia-Western Asia Corridor, speculated to follow the overland Silk Road Economic Belt as depicted in maps released last year by the state-owned Xinhua News Agency, passing through Central Asia, Iran and Turkey to reach Europe

- The China-Pakistan Corridor, which would extend the Karakoram Highway, which already crosses the mountains between China and Pakistan, and build highway and rail links all the way through Pakistan to the port of Gwadar

- The Indochina Peninsula Corridor

- The Bangladesh-China-India-Myanmar Corridor.

Nepal figures is nowhere in these six corridors in relation to BRI. Only a document of National Development and Reform Commission (Ministry of Foreign Affairs) and Ministry of Commerce of the People's Republic of China, March 2015, mentions Nepal in relation to promoting 'the border trade and tourism and culture cooperation between Tibet Autonomous Region and neighboring countries." Nepal is referred to as the neighboring country while elaborating the importance of BRI and international relationships (NDRC, 2018).

\section{Past Attempts at Connectivity}

The United Nations, European Union, Asian Development Bank, Japan, and United States made several attempts on the connectivity both at the individual and multilateral levels much before the launching of BRI. They included transportation and trade facilitation, energy projects, bridges, pipelines, railways, airports to facilitate the movement of goods, services, and people. The UN Economic and Social Commission for Asia and the Pacific (UNESCAP) came out with the idea of a trans-Asian railway, connecting Asia to Europe (Singapore to Istanbul), to assist in postwar reconstruction since the 1960s. Eurasian regional infrastructure network emerged under the aegis of the UN in 1960s. Several projects were launched for a regional infrastructures network. During 1950s, and 1960s, China pursued building an expansion of a transportation network in Northeast China, where heavy industries were located. Rail was chosen over roads to carry huge quantities of raw materials from resource-rich provinces to the country's Manchurian “rust belt" (Rolland, 2017).

China focused on the development of its coastal regions and pursued cross border infrastructure projects. Since 1992, China invested an average of 8.5 percent of its GDP on domestic infrastructure. The Chinese government has launched a series of landmark projects, one more grandiose than the next (Chen \& Woetzel, 2013). They all aimed at unlocking the socioeconomic potential to enable the recipient countries' eventual integration into liberal international order and transforming them from being landlocked to land-linked. Following the collapse of the Berlin Wall in 1989, all the 14 republics of erstwhile Soviet Union fragmented marking the "The End of History" ending the ideological conflict between liberalism and communism. The moment brought the primacy of geo-economics over geopolitics. More attempts were made to promote infrastructures connectivity and economic development to transform post-communist world into a democratized and stable region and integrate them into global economy and rule them based international order.

Japan's initiatives before and during World War II to create a "Greater East Asia Co-Prosperity Sphere"a self-sufficient bloc of countries, under its leadership can be considered a part of enhancing connectivity. In the light of increasing expansion of international economic community beyond national borders, globalization of economic activities, and economic interdependence, Japan launched initiatives to create an 'arc of freedom and prosperity' in Eurasia. Japan's Prime Minister talking to the Japan Association of Corporate Executives in July 1997 recalled Japan's deep-rooted nostalgia for this region stemming from the glory of the days of the Silk Road (Hashimoto, 1997). The "the Central Asian Republics and nations of the Caucasus region have come into existence in this vast area, which we may call the Silk Road region" (Hashimoto, 1997, p. 1). Hashimoto (1997) observed the great efforts made by these Central 
Asian and Caucasian countries to establish affluent and prosperous domestic systems under a new political and economic structure, and to forge peaceful and stable external relations with their neighboring countries. The rich oil and natural gas resources in the Caspian Sea region are having a steadily expanding influence on the world energy supply with a great potential of serving as bridges between European and Asian countries. However, due to economic recession, Japan had to cut budget priorities and was unable to join this mega wagon.

After the end of Cold War, it was realized that without the trust of cooperation, merely racing with arms and colonization and enslavement would not do any good for human kinds. On September 4, 1990, erstwhile Soviet foreign minister Eduard Shevardnadze at the Second International Conference on the Asia-Pacific region said that after the Cold War, Europeans, Asians have reached out toward each other to overcome the walls of division, self-imposing isolation of individual countries, the nightmares of colonial occupation and enslavement, regional conflicts and material inequality. The great Silk Road transcended wars and violence, the thin silk thread of history linked together time and space. It was realized that the slow-moving silk caravans giving way to optical cable technology and electronics could bring together the formerly divided worlds (Shevardnadze, 1990).

Between 1994 and 2002, UNESCAP's secretariat studied existing routes of international importance linking regional capitals or major industrial and commercial hubs. The study focused on the project's economic feasibility and necessary technical standards and requirements. UNESCAP also sought to generate regional dialogue among the potential participants in order to minimize some of the politically induced local difficulties. The Intergovernmental Agreement on the Asian Highway Network (IAAHN) was adopted in November 2003, and the Intergovernmental Agreement on the Trans-Asian Railway Network (IATARN) was adopted in April 2006 (Rolland, 2017). Several institutional cooperation and coordination were needed at different levels to establish a transcontinental network (Rolland, 2017).EU also developed its own vision of an integrated sub-regional infrastructure system. The European Commission launched the Transport Corridor Europe-Caucasus-Asia (TRACECA) assistance program in May 1993 as part of its greater neighborhood diplomacy and attempts to reach out to its newly independent Eastern neighbors.

Between 1996 and 1998, Ukraine, Mongolia, and Moldova joined the existing eight participants (Armenia, Azerbaijan, Georgia, Kazakhstan, Kyrgyzstan, Tajikistan, Turkmenistan, and Uzbekistan), followed by Bulgaria, Romania, and Turkey in March 2000; by Lithuania as an observer in June 2009; and by Iran in July 2009.In September 1998,the Basic Multilateral Agreement on International Transport for Development of the Transport Corridor Europe-the Caucasus-Asia was signed, laying the foundation for further institutionalized regional cooperation on railway and road transportation and commercial maritime navigation, as well as the unification of customs and documentation procedures. The European Bank for Reconstruction and Development also financed a series of projects to modernize transportation infrastructure in some of the TRACECA countries.

Erstwhile Indian Prime Minister, Manmohan Singh, envisaged that one would be able to have "breakfast in Amritsar, lunch in Lahore, and dinner in Kabul (The Hindu 2007). Asian Development Bank (ADB) has been working to meet infrastructure needs in the region for the last five decades. ADB has been playing a role in addressing financing, planning, and institutional arrangements to promote better integration of Asian infrastructures. It has initiated several studies to examine the links between regional roads in the light of growing momentum for regional cooperation and integration (RCI) in Asia. The much-talked Asian Highway network of about 140,000 kilometers (km) of standardized roads crisscrossing many Asian countries aimed at providing links to Europe. ADB's sub regional programs in Asia included among others the Greater Mekong Subregion (GMS) and Central Asia Regional Economic Cooperation (CAREC) programs (Madhur et al., 2009). Madhur et al. (2009) underscore the needs for infrastructure across Asia and the Pacific, with an emphasis on the upgrading of "infrastructure that will set the standard for quality, encourage economic growth, and respond to the pressing global challenge that is climate change." Madhur et al. (2009) reported the estimated cost of ADB as $\$ 550$ billion per year of infrastructure spending in the developing Asia-Pacific between 2010 and 2020. However, this cost has been revised recently to $\$ 1.5-\$ 1.7$ trillion per year through 2030 (ADB, 2017).

\section{Responses to Belt and Road Initiative}

BRI has evoked a variety of responses from governments, commentators and analysts throughout the region and beyond. Countries appear divided to the extent to which they should participate in the 
initiative. Though some expressed overwhelming support for the BRI, while others have shown their reservations, appear reluctant and unwilling to join it. They include among others ASEAN, United States, Japan and India. EU seems willing to cooperate for 'shaping the outcome from within'. They want to 'cooperatively shape future security landscape in line with EU's stated priorities in relations to global governance, state-societal resilience and cooperative regional orders. Europeans believe that this will the best way to influence China on a range of issues of their interests.'

Government of Japan has always viewed this "One Belt, One Road" very critically whether it would contribute to sustainable regional development (Kishida, 2017). Japan wanted the "One Belt, One Road" be open to all countries that meets international standards, and it should be Free and Open Indo-Pacific based on the rule of law. The Foreign Minister of Japan made it clear that Japan is not totally against the project, but cooperation to this project would be based on a case-by-case basis. These conditions include but not limited to matching international standards, transparency, openness, the fiscal ability of the country, and acceptable environmental and social conditions (Kono, 2018). Ever since the emergence of this concept, the Indian security establishment is deeply suspicious of China's Silk Road initiatives. Delhi's strategic community has long objected to China's road construction on land frontiers and port building in the Indian Ocean as "strategic encirclement" (Mohan, 2018). Delhi has expressed concerns over Beijing's push to develop major land and maritime trade routes around India's periphery (Wong, 2018). India has kept aloof, condemning it as a sneaky Chinese scheme to entrap unsuspecting client states in debt (The Economist, 2018).

India was invited to the May 14-16, 2017 Conference on OBOR in China but declined to participate. The official spokesperson of the Government of India, "while sharing international community's desire for enhancing physical connectivity," said, India believed that it should bring greater economic benefits to all in an equitable and balanced manner. Further, the spokesperson expressed clarified that "connectivity initiatives must follow principles of fiscal responsibility to avoid projects that would create unsustainable debt burden for communities; balanced ecological and environmental protection and preservation standards; transparent assessment of project costs; and skill and technology transfer to help long term running and maintenance of the assets created by local communities. Connectivity projects must be pursued in a manner that respects sovereignty and territorial integrity." On China-Pakistan Economic Corridor (CPEC), India views that "no country can accept a project that ignores its core concerns on sovereignty and territorial integrity" (GoI, 2017).

China-India bilateral relations are considered among the most important yet complicated. Given the longstanding territorial disputes and competing in Aksai Chin (disputed Kashmir) and Arunachal Pradesh (North East Frontier Agency) conflicting interests on a variety of issues, power rivalry between them is inevitable. India considered BRI not an international initiative. Indian Foreign Secretary labeled it a national initiative with national interests and it is not incumbent on others to buy it. He referred to "in the absence of agreed security architecture in Asia, it could give rise to unnecessary competitiveness."

China is spreading its influence through infrastructures, aid and investment projects that go under the BRI. The influence is increasing across South Asia with sheer speed. Beijing has made "significant inroads into India's backward by engaging and investing in myriad infrastructures development projects, such as roads, railways, sea ports and airports, in Pakistan, Nepal, Maldives, Sri Lanka, Bangladesh and Myanmar (Blah, 2018).Chinese influence- and investment- have been decisive factors in electoral upsets in some of the countries in Asia, particularly in Pakistan, Malaysia and Sri Lanka the Maldives. Since the West criticized the authoritarian rule of President Abdulla Yameen, he looked to Beijing for support and decided to join the BRI. Beijing established its embassy in Male, and entered into a Free Trade Agreement with Male, which is seen in favor of the later. The defeat of BRI-friendly leader in election in the Maldives is generating momentum for a review of projects under BRI elsewhere also. In Nepal, the communist party of KP Oli won 2017 elections on anti-Indian plank, as he reached out to China to lessen the over dependence on India.

As China's presence in the region expands through BRI, India's ability to influence is seen to be declining. New Delhi seems compelled to adopt a moderate posture. This situation puts China in intense rivalry with India. Also, it brings regional tensions in South Asia for example the tweet from Mahinda Rajapaksa after he was appointed premier after the abrupt dismissal of incumbent Prime Minister Ranil Wickremesinghe. Rajapaksa was warmly greeted by Chinese ambassador in Colombo, and Chinese President Xi did not delay in sending a congratulatory message to Rajapaksa (Financial Times, 2018) 
though the appointment was later nullified by the Supreme Court of Sri Lanka." While most countries, including India, the US, UK and Canada expressed concern and urged Sri Lanka to abide by its constitution, and uphold democracy, Beijing immediately recognized Mr. Rajapaksa as the new prime minister and said it "always follows the principles of non-interference in other countries affairs". This is also the reflection of "their contradictory views on the accommodation of China's interest vis-à-vis those of India (Financial Times, 2018)."

Sri Lankan Prime Minister, Ranil Wickremesinghe, who led his country's delegation to Belt and Road Forum in Beijing on May 14, said, Sri Lanka will leverage its strategic location and connectivity to become the hub of the Indian Ocean. He said, "The Belt and Road Initiative will provide the much needed hard and soft connectivity in the Indian Ocean required for rapid economic and social development." Pointing to the various Chinese-funded projects in Sri Lanka, such as the Hambantota Port, Mattala Airport and the southern expressway, Wickremesinghe said "the BRI complemented the island nation's efforts to build advanced infrastructure (Shrinivasan, 2017)." As the usual western donors were reluctant, to support the post war Sri Lanka to finance infrastructure projects, Sri Lankans see the BRI holding "the prospects of helping to bridge the significant infrastructure financing gap, increase connectivity, link local markets to regional and global value chains, and thereby increase trade and investment in the participating countries (Gooneratne, 2019).”

\section{Fear of Debt Trap}

BRI is also seen loaded with an agenda for Beijing's strategic expansion and fear of debt trap. Countries are fearful that China could ultimately exert its influence to gain ownership of the strategically important ports. Sri Lankan Government leased the Hambantota Port to China for 99 years, as it could not pay back its debt to China. The state-owned China Merchants Port Holding Company will develop the Hambantota Port, in spite of stiff opposition from the local people (Sirilal \& Aneez, 2017). The port of Hambantota is indispensable for China's energy security because the country imports two-thirds of its oil through shipping lanes south of the port. Another example of possible debt trap is from the China-Pakistan Economic Corridor (CPEC). This CPEC is the flagship project of the BRI. The $\$ 46$ billion project launched in 2015 , which was subsequently increased to $\$ 62$ billion over a 15 -yearperiod. It is considered a game changer in Pakistan. It includes energy projects, rail and road connectivity, expressways, infrastructure development and industrial zones. Given the scale and nature of the CPEC, it is called the BRI's 'most politically contentious and strategic project' as it passes through Kashmir - a disputed territory between India and Pakistan.

CPEC will strengthen the relationships between China and Pakistan. These countries are linked by through roads, railways, pipelines, and optical fiber networks. It extends up to Xinjiang province in China via the contested Pakistan-occupied "Kashmir" territory. CPEC will provide access and connect Beijing with the Arabian Sea, which would enable China to transport oil supplies and other energy resources from the Middle East in general and Iran in particular. The CPEC projects will make Pakistan a debtor of China and further add to Pakistan's financial burden. Additionally, CPEC will offer special security cover for the Chinese investments and workforce (Kim 2018).Pakistan plans to transform Gwadar into one of the world's largest port cities by 2055, housing steel mills, terminals for liquefied natural gas, oil fields and other facilities. Pakistan's debt to China is rising (Khan, 2018). Khan (2018) further argued that because Pakistan has to counter weight India and China needs it, thus, Beijing "cannot afford" to bankrupt Pakistan. Thus, China's primary interest in Pakistan is "geopolitical rather than strictly economic, and therefore, for China, repayment of the debt burden will be secondary to maintaining a good political and economic relationship with Pakistan" (Khan, 2018). Khan (2018) does not see any danger of China making Gwadar a military port in the future. Thus, "Gwadar is 100 percent \% commercial." If at all, China needs a military base, she can use Ormara naval base (Lat. 25.201237 ${ }^{0} \mathrm{~N}$ and Long. 64.667350 ${ }^{\circ}$ E) (Yamda, 2018).

Pakistan's trade deficit with China has been rising, and there are concerns about what happens if it is unable to repay its debt. As with other countries that have benefited recently from Beijing's largesse, some in Pakistan worry that the price of such investment could be a huge debt burden (Yamda, 2018). Pakistan's new government led by Imran Khan announced that it is cutting down on loans from the People's Republic of China (PRC) under CPEC and has reduced \$2 billion in loans for rail projects (Siddiqui, 2018). Prime Minister Khan said he would request that Beijing realign CPEC's goals to his 
government's agenda, but PRC authorities reportedly brushed aside his proposals to re-negotiate CPEC deals (Basit, 2018).

Bangladesh joined the BRI to benefit from its economic potentials. Chinese President Xi's visit to Bangladesh in 2016 -the first by a Chinese head of state in 30 years bears more significance. He announced projects amounting to $\$ 26$ billion. Three key BRI projects in Bangladesh include the DhakaJessore rail line, the Payra power plant and the Karnaphuli Tunnel -- the country's first-ever underwater tunnel. Chinese development banks dominate the projects' financing; while Chinese contractors often take over the construction process. Geopolitical issues are seen affecting its actual execution. In 2016, Dhaka turned down China's offer to develop a deep-sea port at Sonadia in favor of Japan's proposal for a deep-sea port just $25 \mathrm{~km}$ away at Matarbari, which was considered to be more beneficial to Bangladesh (Ramachandran, 2016).

Afghanistan showed its early interest in BRI. Welcoming it, Kabul saw it as an initiative reshaping the international development order carrying great significance for human development in the $21^{\text {st }}$ century. It hopes that BRI will work to support the peacebuilding process in Afghanistan, improve trading opportunities connecting with regional rail and road network and help emerge it as an important partner in regional energy market and fighting the regional narcotic drugs.

The implementation of BRI demands collaborative measures among several nations. Given the growing importance and significance of India's profile, India's support is essential for the implementation of BRI. Both the most populous nations are emerging as global powers, andhave done well economically. India, though yet to be a permanent member of the United Nations Security Council carries influence on a variety of issues including on climate change, and international peace and security. China's regional ambitions have better chances of being realized if it can take India on board. Beijing is urging Delhi to jointly develop a trans-Himalayan economic zone of cooperation with Nepal and Bhutan (Mohan, 2019). For emerging and transitional economies which face major infrastructure deficits, Chinese financing such as Silk Road Funds and the Asia Infrastructures investment Bank (AIIB) provides a significant boost to the majority of BRI countries than IMF and World Bank and other including their own domestic financing. They all need money which China can provide.

\section{Nepal's Response to the BRI}

There is a considerable interest in the BRI in Nepal. Early on in 2014, the Sushil Koirala government welcomed China's One Belt One Road (OBOR) initiative (MoFA, 2015). Nepal expressed its desire "to work in close cooperation with China towards enhancing more connectivity and integration between nations and boost their infrastructure, trade, energy sector and tourism, which would ultimately contribute to regional harmony, peace and development" (MoFA, 2015). In view of the desperate needs to expand infrastructures across the country, Nepal looks to benefit from the BRI in which opportunities to harness its vast potential sources - hydropower - for export. Nepal's Foreign Secretary and Chinese Ambassador in Nepal signed a Memorandum of Understanding (MoU) on the framework agreement on China's "One Belt One Road Initiative" (OBOR), marking Nepal's official move to become part of Beijing's ambitious plan to revive ancient Silk Road trade routes. The signing of the agreement took place in Kathmandu on May 12, 2017 just two days ahead of a summit on the Belt and Road Forum for International Cooperation in Beijing. The MoU provides to set up border economic zones and its expansion, and to rebuild ChineseNepali transit road network agreements.

It is expected that BRI will bring the investment into the wide areas and help change the economic map of Nepal through developing local industries and improving the living standards of the low-income groups. The cross-border optical fiber network between Nepal and China, connectivity of its own kind established for the first time between the two neighbors through Geelong-Rasuwgadhi border point, has ended Nepal's sole dependence on India for connecting the Himalayan country with global telecom and internet services (MJ in Xinhua, 2017). MoU's major thrust was described as promoting cooperation on connectivity of facilities, trade and people, financial integration, and promoting people-to-people exchanges. It seeks "to strengthen cooperation in connectivity sectors including transit transport, logistic systems, transport network and related infrastructure development such as railway, road, civil aviation, power grid, information and communication (MJ in Xinhua, 2015)." MOU provides that Nepal and China would work collaboratively with a view to promoting China's investment in Nepali infrastructure, enhancing the regional stability and facilitating economic growth with all the neighbors. "This agreement will bring Nepal and China closer through road connectivity and bring home the Chinese investment" 
(Mahat, 2015). "With the signing of the MoU, a new chapter has begun in the area of foreign investment and trade promotion," adding Nepal would reap benefits from the Chinese project which would expand to Europe and Africa" (Mahat, 2015). "Nepal needs the maximum investment and we want Chinese investment channeled in Nepal through this new project (News18.com, 2017)." BRI was labeled as a significant achievement of Nepal's development endeavour, by connecting capital Kathmandu with Lhasa in Tibet. Describing the agreement as a major development, Mahat said the move is a major step forward in strengthening Nepal-China relations. "Road and railway connectivity is very important for" Nepal, and investment is needed for it. This project would serve the national interest (MJ in Xinhua, 2017).

Nepali Planners and Policy makers termed this agreement as a step to open up a new door with multiple opportunities for infrastructure development and economic growth. BRI will include cross-broader highways, railways, transmission lines and internet connectivity that will contribute to bringing drastic changes in Nepal's socio-economic landscape. As Asian region is seen as the hub of global economy, analysts often argue that the initiative will "improve physical connectivity, deepen economic integration among Asian countries, and thereby unleashing full potential of Asia". With this project, Nepal would be able to reap the benefits to the global value chain through China. It is expected to bring tremendous opportunities creating a win-win situation between China and Nepal (New China, 2017).Nepal expressed its readiness to actively participate in the "Belt and Road" construction, to push Nepal-China all-round cooperation to new and higher levels (MoFA 2018).Talking of "Nepal-China relations and development prospects in trans-Himalayan region', Foreign Minister of Nepal highlighted the development of crossborder railways between Nepal and China as a priority for the Government of Nepal along with other connectivity related infrastructure (Gyawali, 2018). The Minister further said, "Nepal takes pride in seeing China's growing profile on the world stage, both politically and economically. China's role is very important in shaping global agenda for a just and equitable world order (Gyawali, 2018)." With a growing role in international relations for global peace and harmony, China has emerged as a major factor of global stability and growth.

The BRI aims to have peace and prosperity in the region and beyond, which holds far-reaching implications for the development of its neighbours. Transit facility from China will leverage Nepal from transit bottleneck in its international trade. An official of the government of Nepal said the proposed 550 kilometer-long railway would connect China's western Tibet region to Nepal's capital of Kathmandu and will carry goods and passengers. He said the railway will travel over 400 kilometers in China to the Nepal border, and then about another 150 kilometers from the Nepali border to Kathmandu, he said. On priority of Nepal he said, "Our first priority is railway, and second will be hydropower projects and cross-border transmission lines between Nepal and China. (Reuters, 2017)" During the visit of Nepal's Prime Minister to China in June 2018, the two governments agreed to intensify implementation of the MoU on BRI to enhance connectivity, encompassing such vital components as ports, roads, railways, aviation and communications within the overarching framework of trans-Himalayan Multi-Dimensional Connectivity Network. They also agreed to reopen the Zhangmu/Khasa port at an early date; improve the operation of the Jilong/Keyrung port; ensure the sound operation of Araniko Highway; and carry out the repair, maintenance and improvement of Syaphrubesi-Rasuwagadhi Highway and push forward the construction of a bridge over Karnali River at Hilsa of Pulan/Yari port at an early date (MoFA, 2108).

During his visit to China in June 2018, Prime Minister K.P. Oli, during his meeting with his Chinese counterpart Li Keqiang at the Great Hall of the People in Beijing on June 21 presented the list of 35 projects to be funded under the BRI. With sluggish progress in negotiations, the Chinese side has now insisted that Nepal bring down the number of projects under Beijing's flagship foreign policy initiative to the single digit (Giri, 2019). Accordingly, the government is reported to be preparing a list of nine projects which will be funded under the BRI. They include: Upgradation of Rasuwagadhi-Kathmandu road, Kimathanka-Hile road construction, Dipayal to south border with China Tokha-Bidur road, Galchhi-Rasuwagadhi-Kerung 400kv transmission line Keyrung-Kathmandu rail (feasibility study), Tamor hydroelectricity project (762MW) and Phukot Karnali Hydro Electric Project (426MW) (The Kathmandu Post 2019). It demonstrates the confusion and lack of clarity in the Nepali leadership about the projects to be decided under BRI and utter unpreparedness on part of the government.

About Indian concerns on Nepal's participation in the OBOR, Nepal came out strongly to underscore the significance of its ties with India, saying no country can change its geography. An influential cabinet minister was quoted as saying "We have conveyed to China that our joining the Belt and Road initiative is not at the cost of Nepal's relations with India, and its genuine security concerns. And China has 
appreciated it (Ghimire, 2017)." "What we have is only a framework agreement (on OBOR) with China and the modalities of terms and conditions for fund utilization will be worked out later. All such considerations will be made on merit and in keeping with our national interest," said Nepal's ambassador Deep Kumar Upadhyay. He argued "Even China acknowledges that we can't change geography. We need 365 days of continuous supplies. We have joined OBOR, but we have also made it clear to the Chinese that by joining OBOR we don't want to, or mean to, undermine the relationship with India which we are proud of (Parashar, 2017)." In an interview, Prime Minister K.P. Oli made it clear that Nepal decided to join OBOR absolutely in view of its well-judged national interest (Oli, 2018). Our interest in this regard is to develop infrastructure and connectivity with our northern neighbor and this is where our participation in OBOR is focused on. Under the Belt and Road Initiative that Nepal signed with China, Nepal is also expected to receive huge investments to finance its vastly underfunded hydropower, connectivity and tourism sectors. Chinese tourists provide enormous potentials provided if there is a better connectivity and infrastructure in place. The Qinghai-Tibet railway line, which travels through the world's highest plateau, has arrived in Tibet's second city Shigatse and is expected to connect the NepalChina border point of Kerung (also called Gyirong or Kyirong) by 2020 (Upadhyaya, 2018).

China has emerged as an international actor and player. Its role in global peace, security and development is increasing and gaining importance. BRI is seen as China's outreach program to countries in Asia, Europe and Middle East. Never before, China had come with such an outgoing strategy in its foreign policy. BRI stands primus inter pares among Chinese policy initiatives. Issues that are associated with BRI drive China's relationship with the wider world. It tops the talking points with visiting heads of state and government. While projecting China as global power, statements of President Xi reveal a plan for a "risen China sitting at the heart of a Sino-centric regional order" (The Economist, 2018). The Xi Administration project China as the global power. It says BRI does not require recipient countries to transform their sociopolitical systems in exchange for investment. Xi Jinping believes that "countries have different historical processes and realities," and that they have "the right to choose their own development path independently (President Obama, 2015)."

\section{Conclusion}

BRI is a foreign-policy initiative aiming at: strengthening economic collaboration, improving road connectivity, promoting trade and investment, facilitating currency conversion, and bolstering people-topeople exchanges. Overland and maritime Silk Road contains a proposal for the re-establishment of the old sea networks to create a twenty-first century "maritime Silk Road" to foster international connectivity, scientific and environmental research, and fishery activities. Strength abroad begins with strength at home. With economic strength at home, Beijing is strategically moving forward around Asia and in the rest of the world. This is creating a significant geopolitical transformation and challenges. Ever since Xi Jinping became the general secretary of the Communist Party of China (CCP) in 2012, he is increasing his political power by assuming the leadership of most important committees overseeing policy including cyber issues, economic reforms and nation security. His name and ideology 'Xi Jinping Thought on Socialism with Chinese characteristics for a New Era' were enshrined in the party constitution.

BRI reflects the ascendancy of China politically, economically and strategically. It is cited to be a symbol of China's resurgence as a world power, a tool to sustain economic growth, as a vision for the 'uncontested leading power'. China's willingness to play a leading role in reshaping the world is well known. It is therefore important to understand BRI in wider perspectives. Though much has been written and discussed, BRI is still evolving and its study for many seems to be in infancy and rudimentary stage. However, despite some confusion, some twists and bumps in initial phase, BRI has acquired an undeniable momentum. China hopes that realization of the China Dream would "benefit the people of the world" as it is based on principles of "peace, development, cooperation and win-win relations." Given the comprehensive nature of the initiative, it is necessary to think in a holistic manner about its objectives and strategies, ponder its impact, examine environmental standards and local impact of various projects, and evaluate costs and opportunities associated with it. Key findings from the study of eight countries include: project delays concern about ballooning deficits leading to unmanageable debts to Beijing, and concerns related to sovereignty and territorial integrity among others. Critics say BRI fails to take a holistic view of risks and opportunities. China says: BRI is all about connectivity and development with larger ownership and dominant local stakes. 
Projects designed under BRI should be fully aligned with national priorities and selected by host country. Nepal's untapped immense potentials including in tourism, hydropower and development of high altitude medicinal herbs require huge investment. The win-win collaboration can create value chains to their mutual advantage by utilizing these potentials. Nepal should enhance productive capacity and produce goods and services for export to China. This is all the more important when trade deficit with China is assuming alarming proportions. One-way traffic is no win-win cooperation. Only by promoting rule of law, enhancing productive capacity and developing national institutions, building infrastructures, and connectivity, could we enhance trade and investment possibilities.

Nepal is important for both of our neighbours: India and China. Both of our neighbours do not want to cede traditional influence to each other. Nepal's importance is increasing every day in the foreign policy discussions of emerging and established powers. Through world class connectivity, and skillful management of sensitive and fragile geopolitics, Nepal can be a gateway to South Asia for China and gateway to China for India. Entire Himalayan region will benefit, and great civilizational links further enhanced and enriched. Nepal occupies a "special" place in the Indo-Pacific region and must remain stable and prosperous, Washington has said, asserting that America has a "profound stake" in the success of the Himalayan nation. Given its geostrategic location, Nepal's importance in the evolving global strategic scenario has sharply increased. Geography does not argue, it is what it is. Kathmandu needs to conduct its foreign policy sensitively and seriously guided by geopolitical realities, accompanied by good research and studies and should be able to say no to bossy and judgmental decisions of outsiders for preserving the long-term interests of its people and the country.

\section{References}

ADB (2017). Asia infrastructure needs exceed $\$ 1.7$ trillion per year, double previous estimates. Asian Development Bank Press Release. Retrieved January 27, 2019, from https://www.adb.org/news/asiainfrastructure-needs-exceed-17-trillion-year-double-previous-estimates

Basit, A. (2018). Imran Khan's China Visit: A Much-needed Reality Check. IPP review: Know Asia, Sustain Development, Promote Peace. Retrieved January 19, 2019, from http://ippreview.com/index.php/Blog/single/id/842.html

Bijian, Z. (2017). China's 'One Belt, One Road' Marks the Next Phase of Globalization. Retrieved June 9, 2017, from https://www.huffingtonpost.com/entry/china-one-belt-oneroad_us_591c6b41e4b0ed14cddb4527

Bilal, S. (2017). 'India has nothing to fear from China's Belt and Road', The Diplomat. Retrieved January 11, 2017, from http://thediplomat.com/2017/01/india-has-nothing-to-fear-from-chinas-belt-and-road/

Blah, M. (2018). China's Belt and Road Initiative and India's Concerns, Strategic Analysis. Institute for Defence Studies and Analyses, 42(4), 313-332.

Chen, S., \& Woetzel, J. W. (2013). Chinese Infrastructure: The Big Picture. McKinsey Quarterly, June 2013, quoted in Nadege Rolland, China's Eurasian Century? Political and Strategic Implications of the Belt and Road Initiative, 2017.

Clarke, M. (July 2017). The Belt and Road Initiative: China's New Grand Strategy? Asia Policy, P.77.

Economy, E. (2018). China's New Revolution: The Reign of Xi Jinping, Foreign Affairs, May/June 2018, pp. 65-66.

Financial Times, The Editorial Board, (2018). November 15, 2018.

Ghimire, Y. (2017). Next door Nepal: Connections old and new. Retrieved May 22, 2017, from http://indianexpress.com/article/opinion/columns/obor-one-belt-one-road-india-china-next-doornepal-connections-old-and-new-cpec-4667170/

Giri, A. (2019), Nepal trims projects under BRI from 35 to 9, http://kathmandupost.ekantipur.com/news/201901-18/nepal-trims-projects-under-bri-from-35-to-9-at-chinese-call.html,

GoI-Government of India, (2017). Official Spokesperson's response to a query on participation of India in OBOR/BRI Forum. Ministry of External Affairs, Government of India (GoI). Retrieved from https://www.mea.gov.in/media-

briefings.htm?dt1/28463/Official_Spokespersons_response_to_a_query_on_participation_of_India_in _OBORBRI_Forum

Gooneratne, J. (2019). Former Ambassador John Gooneratne quoted in Sudha Ramchandran, The Belt and Road Initiative still afloat in South Asia, Volume 19, Issue 1. Retrieved January 5, 2019, from https://jamestown.org/program/the-belt-and-road-initiative-still-afloat-in-south-asia/ 
Gyawali, P. K. (2018). 'Nepal-China Relations in the Twenty-First Century' Speech by Foreign Minister Pradeep Kumar Gyawali at Roundtable organized by China Reform Forum, Beijing 19 April 2018. Retrieved January 20, 2019, from https://mofa.gov.np/speech-by-foreign-minister-pradeep-kumargyawali-at-roundtable-organized-by-china-reform-forum-beijing/

Khan, M. (2018). Mustaq Khan, an economist and former chief economic adviser at the State Bank of Pakistan.

Kim, A. B. (2018). Is Pakistan About to Be Caught in China's "debt-Trap Diplomacy"? International Economics. Retrieved January 19, 2019, from https://www.heritage.org/internationaleconomies/commentary/pakistan-about-be-caught-chinas-debt-trap-diplomacy

Kishida, F. (2017). Press Conference by Foreign Minister Fumio Kishida. Retrieved May 12, 2017, from http://www.mofa.go.jp/press/kaiken/kaiken3e_000021.html\#topic2

Kono, T. (2018). Extraordinary Press Conference by Foreign Minister Taro Kono. Retrieved January 19, 2019, from http://www.mofa.go.jp/press/kaiken/kaiken4e_000491.html

Kummer, L. (2017) (ed). Stratfor explains how China's Belt and Road Initiative might reshape Europe.

Retrieved January 18, 2019, from https://fabiusmaximus.com/2017/05/18/stratfor-looks-at-belt-androad-initiative-of-china/

Lekhak, R. (2017). Ramesh Lekhak was a Minister of Transportation in the Government of Nepal.

Li, M. (2016). From Look-West to Act West: Xinjiang's Role in China-Central Asian Relations, Journal of Contemporary China, 25(100), 515-528.

Madhur, S., Wignaraja, G., \& Darjes, P. (2009). Roads for Asian Integratio: Measuring Asian Development Bank (ADB)'s Contribution to the Asian Highway Network. ADB Working Paper Series on Regional Economic Integration. No. 37. November 2009.

Mahat, P. S. (2015). Prakash SharanMahat. Nepal's Foreign Minister at the time of signing the MoU on OBOR with China.

MJ in Xinhua (2017a). Nepal-China cross-border fiber network to come into operation in June. XinhuaNet. Retrieved January 19, 2019, from http://www.xinhuanet.com//english/2017-05/27/c_136321051.htm

MJ in Xinhua (2017b). Participation in Belt and Road Initiative serves Nepal's interests: FM .XinhuaNet. Retrieved January 20, 2019, from http://www.xinhuanet.com//english/2017-05/20/c_136300343.htm

MoFA, Ministry of Foreign Affairs (2015). Wang Yi Holds Talks with Minister of Foreign Affairs Mahendra Bahadur Pandey of Nepal. Ministry of Foreign Affairs (MFA) of the People's Republic of China.

MoFA,Ministry of Foreign Affairs (2018). Joint Statement between Nepal and the People's Republic of China. Retrieved June 21, 2018, from https://mofa.gov.np/joint-statement-between-nepal-and-thepeoples-republic-of-china/

MoFA,Ministry of Foreign Affairs (2018), Wang Yi Holds Talks with Foreign Minister Pradeep Kumar Gyawali of Nepal. Ministry of Foreign Affairs of thePeople's Republic of China. Retrieved January 20, 2019, from https://ww.fmprc.gov.cn/mfa_eng/zxxx_662805/t1552712.shtml

Mohan, C. R. (2014). Chinese takeaways, One Belt, One Road. Retrieved August 14, 2018, from http://indianexpress.com/article/opinion/columns/chinese-takeaway-one-belt-one-road/

Mohan, C. R. (2018). Chinese takeaways, One Belt, One Road: New Delhi must make up its mind on Beijing's invitation to jointly build the new silk roads in inner Asia and the Indo-Pacific littoral. Retrieved August 14, 2018, from http://indianexpress.com/article/opinion/columns/chinese-takeawayone-belt-one-road/

NDRC (2015). Actions on Jointly Building Silk Road Economic Belt and 21st Century Maritime Silk Road, 2015/03/28. National Development and Reform Commission (NDRC), Ministry of Foreign Affairs, and Ministry of Commerce of the People's Republic of China, with State Council authorization, March 2015, First Edition 2015. Retrieved January 19, 2019, from http://en.ndrc.gov.cn/newsrelease/201503/t20150330_669367.html. https://www.adb.org/sites/default/files/publication/28511/wp37-roads-asian-integration.pdf

News China (2017). Belt and Road Initiative to boost socio-economic development in Nepal: experts. Retrieved January 20, 2019, from http://www.xinhuanet.com//english/2017-05/15/c_136284982.htm

News18.com (2017). Nepal Formally Joins China's Silk Road Plan Opposed by India. Retrieved January 20, 2019, from https://www.news18.com/news/india/nepal-formally-joins-chinas-silk-road-plan-opposedby-india-1400225.html 
116 | Journal of APF Command and Staff College

Obama, B. (2015). Remarks by President Obama and President Xi of the People's Republic of China in Joint Press Conference," White House, Office of the Press Secretary. Retrieved from https://obamawhitehouse.archives.gov/the-press-office/2015/09/25/remarks-president-obama-andpresident-xi-peoples-republic-china-joint

Oli, K. P. (2018). Prime Minister K.P. Oli: Nepal's participation in OBOR in its national interests, interview with the Times of India. Retrieved April 5, 2018, from

https://timesofindia.indiatimes.com/india/nepals-participation-in-obor-in-its-national-interest-nepal$\mathrm{pm} /$ articleshow/63632542.cms

Parashar, S. (2017). Nepal will carefully weigh use of funds from China: Nepal. Retrieved January 20, 2019, from

http://timesofindia.indiatimes.com/articleshow/58830864.cms?utm_source=contentofinterest\&utm_m edium=text\&utm_campaign=cppst

Qayyum, S. (2015). The Grand Design of China's New Trade Routes: Forecast. Retrieved January 19, 2019, from https://worldview.stratfor.com/article/grand-design-chinas-new-trade-routes

Ramachandran, S. (2016). China's Sinking Port Plans in Bangladesh. China Brief. Vol. 16 (10). The Jamestown Foundation: Global Resource and Analysis. Retrieved January 19, 2019, from https://jamestown.org/program/chinas-sinking-port-plans-in-bangladesh/

Rana, K. S. (2017). China's Belt and Road Initiative (BRI): Impact on India \& its China Diplomacy. Institute of Chinese Studies. ICS. Delhi. ICS Occasional Paper No. 16. First Published in September 2017.

Reuters (2017). Nepal and China to Build \$8 Billion Cross-Border Rail Link The two countries had been in discussions for the past five months about the project, which could cost \$7-8 billion and take up to eight years to complete. Retrieved January 20, 2019, from https://thewire.in/external-affairs/nepalchina-to-build-cross-border-rail-link

Rolland, N. (2015), China's National Power: A Colossus with Iron or Clay Feet?, in Ashley J. Tellis with Alison Szalwinski and Michael Wills (ed), Foundations of National Power in the Asia-Pacific, The National Bureau of Asian Research, Seattle and Washington D.C., 2015.

Rolland, N. (2017). China's Eurasian Century? Political and Strategic Implications of the Belt and Road Initiative, The National Bureau of Asian Research, Seattle and Washington D.C., 2017.

Shevardnadze, E. (1990). Shevardnadze's statement at Conference on Asia-Pacific. Soviet News. Retrieved from http://www.t-k-p.net/yayinlar/cddrt/sovietnews/ sovietnews\%201990/sovietnews_6542_0990.pdf quoted in Nadege Rolland (2017) China's Eurasian Century? Political and Strategic Implications of the Belt and Road Initiative, n. 20.

Shrinivasan, M. (2017). Ranil Wickremesinghe hails China's connectivity project. The Hindu. Retrieved January 19, 2018, from https://www.thehindu.com/news/international/ranil-wickremesinghe-hailschinas-connectivity-project/article18468649.ece?homepage=true

Siddiqui, Z. M. (2018). Cost of railways project under CPEC cut by \$2bn. Dawn. Retrieved January 19, 2019, from https://asia.nikkei.com/Spotlight/Cover-Story/Is-China-s-Belt-and-Road-working-A-progressreport-from-eight-countries

Sirilal, R. \& Aneez, S. (2017). Sri Lanka wants to reduce China's stake in strategic port deal. Retrieved January 19, 2019, from https://www.reuters.com/article/china-silkroad-sri-lanka/sri-lanka-wants-toreduce-chinas-stake-in-strategic-port-deal-idUSL3N1H41SN

Stratfor (2018). Retrieved June 22, 2018, from https://worldview.stratfor.com/article/geopolitics-lookingback-2018

The Economist (2017), China and the West, At the sharp end, Retrieved December 14, 2017, from https://www.economist.com/briefing/2017/12/14/how-chinas-sharp-power-is-muting-criticism-abroad

The Economist (2017). 'Why India and Pakistan hate each other'. Retrieved from https://www.economist.com/news/special-report/21725099-three-score-and-ten-years-aftertheiracrimonious-split-india-and-pakistan-remain

The Economist (2018), Briefing: China's Belt and Road Initiative: Gateway to Globe. Retrieved July 28, 2018, from https://www.economist.com/briefing/2018/07/26/china-has-a-vastly-ambitious-plan-toconnect-the-world

The Economist (2018). China and India: Prickly peers. Retrieved April 28, 2018, from https://www.economist.com/asia/2018/04/26/china-and-india-are-trying-to-get-along-better

The Editorial Board (2018). Beijing: The elephant in the room in Colombo. Ranil Wickremesinghe and Maithripala Sirisena apparently differ on China's interests vis-à-vis those of India. Retrieved 
December 18, 2018, from https://www.telegraphindia.com/opinion/the-elephant-in-the-room-incolombo-is-beijing-as-wickremesinghe-and-sirisena-differ-on-india-s-and-china-sinterests/cid/1679357

The Hindu (2007). Retrieved December 25, 2015, from https://www.india.com/news/india/breakfast-in-kabullunch-in-lahore-dinner-in-delhi-how-narendra-modi-fulfilled-manmohan-singhs-dream-813525/

The Kathmandu Post (2019). Retrieved from http://kathmandupost.ekantipur.com/news/2019-01-18/nepaltrims-projects-under-bri-from-35-to-9-at-chinese-call.html

The Times of India (2017). Assam's vision is to be a gateway to Southeast Asia. Open trade routes connecting Myanmar, Bangladesh, Bhutan, China. Retrieved 12 June, 2017, from

http://blogs.timesofindia.indiatimes.com/the-interviewsblog/assams-vision-is-to-be-gateway-tosoutheast-asia-open-trade-routes-connecting-myanmar-bangladeshbhutan-china/

Upadhyaya, A. (2018). PM's visit to Delhi signals a new equilibrium. Retrieved April 5, 2018 from https://indianexpress.com/article/opinion/nepal-pm-kp-sharma-oli-visit-to-delhi-signals-a-newequilibrium/

Wissenbach, U. \& Wang, Y. (2017). 'African Politics meets Chinese Engineers: The Chinese built Standard Gauge Railway Project in Kenya and East Africa', SAIS-CARI Working Paper, No.13. Retrieved from http://www.saiscari.org/s/SGR-v4.pdf

Wong, C. H. (2018). Indian and Chinese leaders vow better communication, more trade, The Wall Street Journal, April 28, 2018. Xi, J. (2013). Speech by President Xi Jinping at Nazarbayev University see Xi Jinping, "Promote Friendship between Our People and Work Together to Build a Bright Future". Speech given at Nazarbayev University. Retrieved September 7, 2013, from http://www.fmprc.gov.cn/ce/cebel/eng/zxxx/t1078088.htm

Xi, J. (2014), The Governance of China, Beijing: Foreign Languages Press, 2014.

Xi, J. (2017). Keynote speech by President Xi Jinping at the opening ceremony of the Belt and Road Forum (BRF) for International Cooperation: Work Together to Build the Silk Road Economic Belt and The $21^{\text {st }}$ Century Maritime Silk Road. Retrieved May 14, 2017, from http://www.xinhuanet.com/english/2017-05/14/c_136282982.htm

Xi, J. (2013). "Promote Friendship between Our People and Work Together to Build a Bright Future" (speech given at Nazarbayev University, Astana). Retrieved September 7, 2013 from http://www.fmprc.gov.cn/ce/cebel/eng/zxxx/t1078088.htm

Yamda, G. (2018). Is China's Belt and Road working? A progress report from eight countries Beijing's infrastructure push clouded by project delays and mounting debt. Nikkei: Asian Review. Retrieved January 19, 2019, from https://asia.nikkei.com/Spotlight/Cover-Story/Is-China-s-Belt-and-Roadworking-A-progress-report-from-eight-countries

Yu, H. (2013). China's Belt and Road Initiative and Its Implications for Southeast Asia. Asia Policy, 24, 117122.

Yu, H. (2017). Motivation behind China's 'One Belt, One Road' Initiatives and Establishment of the Asian Infrastructure Investment Bank. Journal of Contemporary China, 26(105), 353-368. 